\title{
Література:
}

1. Лагутенко O. GRAPHEIN ГРАФІКИ. Нариси з історії української графіки XX століття. К.: Грані-Т, 2007. 168 с.

2. Шевченко В. Композиція плаката: Навч. Посіб. Х.: Колорит, 2007. 133 с., іл..

3. https://back-in-ussr.com/2018/03/sovetskie-agitplakaty-budbditelen.html

4. https://oleksandr-klymenko.com/uk/uspishna-kraina/

5. https://ru.depositphotos.com/vectorimages/\%D0\%B7\%D0\%B2\%D0\%B5\%D0\%B7\%D0\%B4\%D0\%B0$\% \mathrm{D} 1 \% 81 \% \mathrm{D} 1 \% 81 \% \mathrm{D} 1 \% 81 \% \mathrm{D} 1 \% 80 . \mathrm{html}$

6. https://ru.wikipedia.org/wiki/\%D0\%9F\%D1\%80\%D0\%BE\%D0\%BF $\% \mathrm{D} 0 \% \mathrm{~B} 0 \% \mathrm{D} 0 \% \mathrm{~B} 3 \% \mathrm{D} 0 \% \mathrm{~B} 0 \% \mathrm{D} 0 \% \mathrm{BD} \% \mathrm{D} 0 \% \mathrm{~B} 4 \% \mathrm{D} 0 \% \mathrm{~B} 0 \_\% \mathrm{D} 0 \% \mathrm{~B} 2 \_\%$ $0 \% \mathrm{~A} 1 \% \mathrm{D} 0 \% \mathrm{~A} 1 \% \mathrm{D} 0 \% \mathrm{~A} 1 \% \mathrm{D} 0 \% \mathrm{~A} 0 \# /$ media/\%D0\%A4\%D0\%B0\%D0\%B9 \%D0\%BB:Soviet_Poster_4.jpg

7. https://sapiens.com.ua/ua/publication-single-page?id=140

DOI https://doi.org/10.30525/978-9934-26-004-9-77

\section{КОНФЛІКТНІСТЬ ЯК ПРИНЦИП МУЗИЧНОЇ ДРАМАТУРГІЇ У ФІЛЬМІ «ВОЛОДАР ПЕРСНІВ»}

\author{
Пожарська А.-О. Ю. \\ аспірант кафедри музикознавства та музичної освіти \\ Інституту мистеитв Київського університету імені Бориса Грінченка \\ м. Київ, Украӥна
}

Кіномузика посідає особливе місце у музичному мистецтві: вона водночас має характеристики автономного музичного твору та $\epsilon$ частиною синтетичного цілого - кінопродукту.

Дослідження кіномузики фільмів у жанрі фентезі є відносно молодим у музикознавстві. Наразі більшість науковців вивчає музику культового фільму «Володар Перснів», зокрема гармонічні і мелодичні особливості тем-лейтмотивів, а також їх роль у художній драматургії фільму [3]. У своїх роботах дослідники кіномузики «Володаря Перснів» розглядають музичну драматургію як частину художньої, тобто, як підпорядковану загальній драматургічній лінії фільму [6]. Проте Н. Дерда [2] висловила 
припущення, що музика з фільму «Володар Перснів» може мати власну музичну драматургію.

Вивченням особливостей музичної драматургії у кінематографі займались Т. Шак [5], О. Бут [1], М. Корбелла [7]. Проте музична драматургія у кіно, хоч і підпорядковується загальному драматичному розвитку кінофільму, має риси музичної драматургії автономної музики. Тому доречним $є$ застосування до музичної драматургії кінофільмів методів вивчення музичної драматургії автономної музики, запропонованих, зокрема, Т. Черновою [4].

Серед принципів музичної драматургї̈ автономного музичного твору, виділених Т. Черновою, можна назвати орієнтацію на композиційні масштаби музичного часу, тематичну спрямованість, сюжетність, переважання композиційного рівня організації, централізація тематичних відносин та інші [4, с. 59]. До одного з найважливіших принципів належить принцип конфліктності [4, с. 56].

Конфлікт $є$ рушійною силою драми як роду літератури. Поняття «драматургія»є похідним від поняття «драми», тому успадковує від неї значення конфлікту, яке перейшло із літературної сфери в музичну [4, c. 34].

Конфліктність здійснюється через закономірну зміну сюжетних ситуацій. Розвиток конфліктної ситуації має проходити упорядковано, логічно i результативно. Виділяють кілька стадій: формування (експозиція діючих сил), зав’язка (їх зіткнення), розгортання (боротьба), кульмінація, розв'язка і т. д. У більш крупному плані у розгортанні будьякого конфлікту можна виділити початок, середину і кінець, тобто три фази. У музиці дана трифазовість втілюється у вигляді динамізованої тричастинної репризності, у якій перша частина виконує роль експозиції конфлікту, друга - його розробки, третя - репризи, що $є$ розв'язкою конфлікту [4, с. 56].

Носіями конфлікту є музичні теми. Розвиток конфлікту втілюється у зіткненні музичних тем, інтенсивному i цілеспрямованому їх перетворенні, закономірній зміні тональностей. Важливим стає ретельний відбір тематичного матеріалу, встановлення логіки тонального плану, координація тематичних, жанрових і тональних співвідношень, що дозволяє виразити внутрішній конфлікт [4, с. 56-57].

У драматичному музичному творі повинно бути не менше двох контрастних тем. При наявності більше двох тем виникає, як правило, підпорядкування частини мелодичного матеріалу, в результаті якого виділяються основні теми - носії сюжетних ліній - i теми епізодичні. 
Така тематична організація втілює принцип централізації тематичних відносин [4, с. 57].

Характерною ознакою теми у драматичному музичному творі $\epsilon$ iii здатність до розвитку. Будучи єдиною за змістом, вона може містити внутрішні протиріччя [4, с. 57-58].

Таким чином, до ознак конфліктності у музичній драматургії твору можна віднести: 1) наявність не менше двох контрастних тем, які співставляються і змінюються в процесі музико-драматичного розвитку; 2) виділення серед музичних тем двох основних та багатьох їм підпорядкованих; 3) інтенсивне перетворення музичних тем в процесі їх драматичного розвитку; 4) динамізована тричастинна репризність 3 екпозицією, розробкою і репризою; 5) сюжетність - наявність закономірної зміни таких стадій, як експозиція діючих сил, зав'язка - їх зіткнення, розвиток подій (боротьба), кульмінація, розв'язка.

Відшуковуючи дані ознаки в музиці фільму «Володар Перснів», можна помітити, що не всі вищезгадані ознаки конфліктності добре прослідковуються. Яскраво виділяється перша ознака: у кіномузиці «Володаря Перснів» $є$ значна кількість музичних тем, багато з яких $\epsilon$ контрастними між собою. Це проявляється, перш за все, у їх ладових і мелодичних особливостях: музичні теми протагоністів твору (Братства Персня, хоббітів) є мажорними, розлогими і наспівними, гамоподібними, 3 опорою гармонії на стійкі ступені - тоніку і домінанту. Музичні ж теми антагоністів - темного володаря Саурона та мага-зрадника Сарумана - $\epsilon$ короткими, різкими, мінорними, насиченими дисонансами.

У музиці «Володаря Перснів» важко виділити дві головні теми, між якими відбувається музичний конфлікт. Фільм сам по собі має складну тричастинну будову, де кожна з частин $є$ завершеним твором і водночас частиною цілого. Дана властивість поширюється і на музику. Тому на рівні кіномузики окремого фільму можна спробувати виділити головні теми за їх наявністю у кульмінації. У кульмінації першого фільму, «Братство Персня», стикаються тема Сарумана та тема Братства; у другому фільмі, «Дві вежі», це теми Сарумана, тема Рохану, змінений варіант теми Галадріель та тема Братства; у третьому фільмі, «Повернення короля», відбувається протистояння тем Гондору, Рохану, Братства та теми Саурона. Вищезгадані теми можна згрупувати за музичними характеристика (про спільні риси теми Саурона і теми Сарумана було зазначено вище; теми Гондору і Братства мають у своїй структурі схожі гамоподібні закличні інтонації, а тема Галадріель у зміненому вигляді зазнала впливу другої половини теми Братства). Тим 
не менш, вони є недостатньо централізованими: теми однієї групи мають спільні риси, проте їх помітити важче, ніж відмінності.

У музичній структурі також багато другорядних тем. Одні 3 них не впливають на загальний драматичний розвиток музики i використовуються лише в окремих епізодах (тема павучихи Шелоб або тема ельфів Рівенделу). Інші ж згодом вплітаються у музично-драматичну структуру і виконують свою роль у розвитку музичного конфлікту (тема Галадріель під впливом теми Братства набуває бойових рис і відіграє значну роль у кульмінації другого фільму). До другорядних фактично відносяться усі теми, які характеризують хоббітів, проте у музичній сюжетності вони використовуються як символ безпечного дому.

Щодо третьої ознаки (інтенсивного перетворення тем в процесі розвитку), то вона реалізовується частково: так, теми зазнають змін і перетворюються, утворюючи нові теми або підтеми (як вищезгадана тема Галадріель), проте основні музичні теми залишаються впізнаваними протягом усього твору, їх зміни є незначними.

Тричастинна репризність $є$ характерною для музики фільму «Володар Перснів». У розв'язці усіх трьох фільмів переможно звучать теми головних героїв (це теми Братства, Гондору, Рохану та Ширу).

Досліджуючи сюжетність як п’яту ознаку, можна помітити, що у музичній структурі кожного фільму можна виділити пролог, експозицію, зав'язку, розвиток подій, кульмінацію, розв'язку і репризу, у кінці останнього фільму є ще епілог. Представлені у експозиції теми протягом розвитку подій співставляються одне 3 одним та 3 іншими темами, інтенсивно взаємодіють у кульмінації (нерідко - за участю змінених другорядних тем), і у розв'язці звучать теми переможців. Про пари тем, які взаємодіють у кожному фільмі, було згадано вище.

Таким чином, музична драматургія фільму «Володар Перснів» має більшість ознак конфліктності, що дозволяє відносити іiі до змішаноконфліктного типу.

\section{Література:}

1. Бут О. Драматургічні функції та концепції кіномузики. КіноTeamp, 2010. № 02(88). С. 24-26.

2. Дерда Н. Стилевые открытия Говарда Шора в кинотрилогии «Властелин колец». Музика на початку третього тисячоліття, 2017. №3. C. 1-11 URL: http://musikology.com.ua/upload-files/vip_3/Derda_3.pdf. (дата звернення: 19 
3. Пожарська А.-О. Музика кінофільмів жанру фентезі у науковому полі досліджень. Актуальні питання гуманітарних наук. 2020. Т. 1. № 31. С. 196-201. https://doi.org/10.24919/2308-4863.1/31.213775

4. Чернова Т. Ю. Драматургия в инструментальной музыке. Москва: «Музыка», 1984. 144 с.

5. Шак Т.Ф. Музыка в структуре медиатекста (на материале художественного и анимационного кино): дис. ... доктора мистецтвознавства: 17.00 .02 / Краснодарский государственный университет культуры и искусств. Краснодар, 2010. 464 с.

6. Bernanke J. Howard Shore's ring cycle: the film score and operatic strategy. Studying the event film: the Lord of the rings / Edited by H. E. Margolis. Manchester, UK: Manchester University Press, 2008. P. 176-184

7. Corbella M. Notes for a dramaturgy of sound in Fellini's cinema: the electroacoustic sound library of the 1960s. Music and the Moving Image, 2011. Vol. 4. № 3. P. 14-30. 